\title{
Effect of different levels of sunflower meal and multi-enzyme complex on performance, biochemical parameters and antioxidant status of laying hens
}

\author{
P. Baghban-Kanani ${ }^{1}$, B. Hosseintabar-Ghasemabad ${ }^{1}$, S. Azimi-Youvalari ${ }^{2}$, A. Seidavi ${ }^{3}$, T. \\ Ayaşan $^{4}$, V. Laudadio ${ }^{5}$ \& V. Tufarelli ${ }^{5 \#}$ \\ ${ }^{1}$ University of Tabriz, Department of Animal Science, Tabriz, Iran \\ ${ }^{2}$ Urmia University, Department of Animal Science, Urmia, Iran \\ ${ }^{3}$ Department of Animal Science, Rasht Branch, Islamic Azad University, Rasht, Iran \\ ${ }^{4}$ Eastern Mediterranean Agricultural Research Institute, Adana, Turkey \\ ${ }^{5}$ Section of Veterinary Science and Animal Production, Department of DETO, University of Bari 'Aldo Moro', Valenzano, \\ Italy
}

(Received 12 December 2017; Accepted 15 January 2018; First published online 19 January 2018)

Copyright resides with the authors in terms of the Creative Commons Attribution 4.0 South African Licence.

See: http://creativecommons.org/licenses/by/4.0/za

Condition of use: The user may copy, distribute, transmit and adapt the work, but must recognise the authors and the South African Journal of Animal Science.

\begin{abstract}
This study was designed to evaluate the effects of different sunflower meal (Helianthus annus; SFM) levels and a multi-enzyme complex (Natuzyme $\mathrm{P}_{50}$ ) on performance, biochemical parameters and antioxidant status of laying hens. A total of $288 \mathrm{Hy}$-Line W-36 laying hens (39-wk-old) were divided into six groups with six replicates per group (eight birds per replicate) and fed one of the six experimental diets. A corn-soybean meal-based diet was formulated and used as control diet. The experimental treatments consisted of three levels of SFM $(0,10$, and $20 \%$ ) and two levels of multi-enzyme complex ( 0 and $250 \mathrm{~g} / \mathrm{ton})$. The feeding trial lasted 10 weeks. The results showed that the egg production, egg weight and mass, egg specific gravity, shell strength and thickness, Haugh unit, shape index, triglyceride content, plasma glutathione peroxidase (GSH) activity, and malondialdehyde (MDA) were not influenced by dietary treatments; however, the feed consumption, yolk cholesterol, low-density lipoprotein (LDL) and high-density lipoprotein (HDL) cholesterol were significantly affected by feeding SFM compared to the control. In conclusion, the supplementation of SFM up to $20 \%$ in diet with multi-enzyme complex in laying hens did not appear to cause any adverse effects on egg production and quality as well on antioxidant status in laying hens.
\end{abstract}

Keywords: Enzymes, laying hen, performance, sunflower meal, yolk cholesterol

\# Corresponding author: vincenzo.tufarelli@uniba.it

\section{Introduction}

The gradual increase in the world's poultry production concomitantly increases the need for ingredients to supply protein for diets. Cereals constitute about $60-70 \%$ of diets to meet the energy requirements of poultry, whereas oilseeds contribute to cover the dietary protein requirements of birds (Senkoylu \& Dale, 1999). Soybean meal (SBM) is the main protein source in poultry rations given its high nutritional value. Most of the European and Asian countries import this feed ingredient. Therefore, cottonseed, rapeseed, sunflower and groundnut meals have been suggested as an alternative protein sources for poultry diet (Rezaei \& Hafezian, 2007; Laudadio et al., 2014b; Laudadio et al., 2014c).

In recent years, the cultivation of some oilseeds, such as sunflower (Helianthus annus), has been growing in many European and Asian countries. Sunflower contains about $45 \%$ of oil and a valuable amount of protein and B-group vitamins. In addition, it can be harvested up to two or three times per year in tropical and sub-tropical areas, being a valuable alternative for oil producers and feed mill sector (Rezaei \& Hafezian, 2007). However, the use of sunflower meal (SFM) in poultry diet is limited by variations in its chemical composition and the two main components restricting its use are high fiber and low lysine contents (Rezaei \& Hafezian, 2007; de Morais Oliveira et al., 2016). Most of the studies evaluated the use of sunflower in poultry feeding and reported that a high level of SFM can be used in laying hens' diet without any negative effect on egg performance and quality (Tsuzuki et al., 2003; Casartelli et al., 2006; Laudadio et al., 2014a). However, levels higher than $5 \%$ in diet require supplementation of lysine. The SFM is a good 
protein source and its content depends by dehulling, air-classification, and oil extraction processes (Laudadio et al., 2013). Amino acid composition of SFM is also variable, with lysine and methionine levels ranging from 0.56 to $0.66 \%$ and from 0.33 to $0.50 \%$, respectively (Tsuzuki et al., 2003). Therefore, the use of multi-enzymes in diet may increase digestibility of the protein improving laying hens' performance. Exogenous enzymes have been used in the poultry industry to reduce the anti-nutritional factors effects and to improve the utilization of dietary energy and protein, thus leading to enhanced poultry production (Sateri et al., 2017). It is, however, understood that the responses to exogenous enzymes in poultry species with respect to performance has been variable and depends on many factors, such as bird age and quality or type of diet used (Tufarelli et al., 2007; Lee et al., 2014; Sateri et al., 2017). Since SFM contains substantial concentrations of cell-wall material and a high fiber level that could affect the nutritive value of meal, the use of exogenous enzyme may be justified to improve the accessibility of cell contents to digestive enzymes (Alagawany et al., 2015). Khan et al. (2006) reported that supplementation of SFM-based diets including a multi enzyme improved feed conversion ratio and egg weight.

Therefore, the objective of this study was to investigate the effects of different SFM levels and a multiple enzyme complex on productive performance, biochemical parameters, and antioxidant status of laying hens.

\section{Materials and Methods}

In this experiment the chemical composition of SFM was determined according to AOAC (2000), as reported in Table 1. The metabolizable energy (ME) content of SFM was estimated based on the following equation (NRC, 1994):

$$
M E n=26.7(D M)+77(E E)-51.22(C F)
$$

where DM, EE, and CF are dry matter, ether extract, and crude fiber percentage of SFM, respectively.

Table 1 Nutrient composition and metabolizable energy content of sunflower meal (\% DM)

\begin{tabular}{ccccccccccc}
\hline Nutrients & DM & $\begin{array}{c}\text { Crude } \\
\text { Protein }\end{array}$ & $\begin{array}{c}\text { Ether } \\
\text { Extract }\end{array}$ & $\begin{array}{c}\text { Crude } \\
\text { Fiber }\end{array}$ & Ash & NFE & $\begin{array}{c}\text { ME } \\
(\mathbf{k c a l} / \mathbf{k g})\end{array}$ & $\mathbf{C a}$ & $\mathbf{P}$ & $\mathbf{N a}$ \\
\hline$\%$ & 91.20 & 36.20 & 2.52 & 22.41 & 8.00 & 40.87 & 1943.2 & 0.47 & 0.79 & 0.25
\end{tabular}

DM, dry matter; NFE, nitrogen free-extracts; ME, metabolizable energy.

A total of 288, 39-week-old Hy-Line W-36 White Leghorn laying hens were assigned to six dietary treatments with six replicates having eight hens, in a $3 \times 2$ factorial arrangement by completely randomized design (CRD). The hens were allocated in individual cages $(41 \times 23 \times 43 \mathrm{~cm})$ and four cages were considered as replicate. Before starting the trial, egg production of hens was measured individually for one month and hens with equal egg production were placed in each replicate. Diets were formulated based on linear programming by using UFFDA software (Pesti \& Miller, 1992). Treatments consisted of three levels (0, 10 and $20 \%$ ) of SFM inclusion and two levels of multi-enzyme complex (0 and 250g/ton) (Table 2).

Feed and water were offered ad libitum during the experiment. Light was provided for $16 \mathrm{~h}$ per day during the trial period. The multi-enzyme preparation used, Natuzyme $\mathrm{P}_{50}$ (Bioproton Pty Ltd., Sunnybank, Australia) contained: xylanase $(10,000,000 \mathrm{unit} / \mathrm{kg})$, cellulase $(5,000,000 \mathrm{unit} / \mathrm{kg}), \beta$-glucanase $(1,000,000$ unit $/ \mathrm{kg})$, pectinase $(140,000 \mathrm{unit} / \mathrm{kg})$ from Trichoderm areesei and Trichoderma longibrachiatum. It also contained protease $(6,000,000 \mathrm{unit} / \mathrm{kg})$ and phytase $(500,000 \mathrm{unit} / \mathrm{kg})$ from Aspergillus niger, and $\alpha$-amylase $(1,800,000$ unit $/ \mathrm{kg})$ from Bacillus subtilis. Birds were fed a balanced commercial diet as their daily requirement for two weeks prior the commencement of the study to allow them to adapt and reach a standard level of egg production (data not shown). The experiment lasted 10 weeks.

During the trial, daily feed intake, feed conversion ratio, egg weight and mass, egg production, egg specific gravity, Haugh index, and mortality rate were measured. Body weight of hens was recorded at the beginning and at the end of the experiment. Feed intake was recorded weekly by subtracting the left-over feed from the quantity supplied to animals. Eggs from individual hens were collected daily and weighed. The egg production and feed efficiency were calculated as rate of production per hen per day and feed intake/egg mass. Four hens from each replicate were randomly selected and blood from brachial wing vein was collected every two weeks and sampled into EDTA-contained tubes and centrifuged at $3000 \mathrm{rpm} \times 10$ min for plasma collection to determine glutathione peroxidase (GSH) activity, malondialdehyde (MDA) 
concentration, triglycerides, total cholesterol, low-density lipoprotein (LDL) and high-density lipoprotein (HDL) cholesterol, using commercial diagnostic kits. At the end of the experiment, a total of 30 eggs from each treatment were collected to determine yolk cholesterol content (Elkin and Rogler, 1990). Atherogenic index of eggs ( $20 \%$ of all produced eggs) was calculated using the equation proposed by Ulbricht and Southgate (1991). Samples were stored at $-80^{\circ} \mathrm{C}$ for further analyses.

Table 2 The ingredients and chemical composition of experimental diets fed to laying hens

\begin{tabular}{|c|c|c|c|c|c|c|}
\hline Treatments & $\mathrm{T} 1^{1}$ & $\mathrm{~T}^{2}{ }^{2}$ & $\mathrm{T3}^{3}$ & $\mathrm{T4}^{4}$ & $T 5^{5}$ & $T 6^{6}$ \\
\hline \multicolumn{7}{|l|}{ Ingredients (\%) } \\
\hline Corn & 61.47 & 52.83 & 44.17 & 61.43 & 52.75 & 44.05 \\
\hline Soybean meal & 23.57 & 20.52 & 17.48 & 23.57 & 20.57 & 17.56 \\
\hline Sunflower meal & -- & 10.00 & 20.00 & -- & 10.00 & 20.00 \\
\hline Oyster Mineral & 9.67 & 9.80 & 9.93 & 9.67 & 9.80 & 9.93 \\
\hline Vegetable oil & 2.40 & 4.33 & 6.25 & 2.42 & 4.34 & 6.27 \\
\hline Dicalcium Phosphate & 1.88 & 1.52 & 1.16 & 1.88 & 1.52 & 1.16 \\
\hline Vitamin Premix $^{7}$ & 0.25 & 0.25 & 0.25 & 0.25 & 0.25 & 0.25 \\
\hline Mineral Premix ${ }^{8}$ & 0.25 & 0.25 & 0.25 & 0.25 & 0.25 & 0.25 \\
\hline Salt & 0.20 & 0.20 & 0.20 & 0.20 & 0.20 & 0.20 \\
\hline DL-Methionine & 0.30 & 0.23 & 0.17 & 0.30 & 0.23 & 0.17 \\
\hline Lysine & 0.00 & 0.03 & 0.07 & 0.00 & 0.03 & 0.07 \\
\hline Threonine & 0.01 & 0.04 & 0.07 & 0.01 & 0.04 & 0.07 \\
\hline Enzyme & 0.00 & 0.00 & 0.00 & 0.02 & 0.02 & 0.02 \\
\hline \multicolumn{7}{|l|}{ Chemical Composition (\%) } \\
\hline $\mathrm{AME}_{\mathrm{n}}(\mathrm{kcal} / \mathrm{kg})$ & 2830 & 2830 & 2830 & 2830 & 2830 & 2830 \\
\hline Crude Protein & 15.25 & 15.25 & 15.25 & 15.25 & 15.25 & 15.25 \\
\hline Ether Extract & 5.02 & 7.41 & 9.88 & 5.03 & 7.43 & 9.82 \\
\hline Crude Fiber & 2.78 & 4.65 & 6.52 & 2.78 & 4.65 & 6.52 \\
\hline Linoleic Acid & 2.58 & 3.35 & 4.12 & 2.59 & 3.36 & 4.13 \\
\hline Calcium & 4.35 & 4.35 & 4.35 & 4.35 & 4.35 & 4.35 \\
\hline Available Phosphorus & 0.46 & 0.46 & 0.46 & 0.46 & 0.46 & 0.46 \\
\hline Sodium & 0.11 & 0.13 & 0.15 & 0.11 & 0.13 & 0.15 \\
\hline Potassium & 0.61 & 0.63 & 0.64 & 0.61 & 0.63 & 0.64 \\
\hline Methionine & 0.52 & 0.49 & 0.46 & 0.52 & 0.49 & 0.46 \\
\hline Methionine+Cysteine & 0.67 & 0.67 & 0.67 & 0.67 & 0.67 & 0.67 \\
\hline Lysine & 0.78 & 0.79 & 0.79 & 0.78 & 0.79 & 0.79 \\
\hline Arginine & 0.97 & 1.07 & 1.18 & 0.97 & 1.07 & 1.18 \\
\hline
\end{tabular}

${ }^{1}$ Control-diet,

${ }^{2} 10 \%$ SFM without enzyme,

${ }^{3} 20 \%$ SFM without enzyme,

${ }^{4}$ Control-diet with $250 \mathrm{~g} /$ ton enzyme,

$510 \%$ SFM with $250 \mathrm{~g} /$ ton enzyme,

${ }^{6} 20 \%$ SFM with $250 \mathrm{~g}$ /ton enzyme,

${ }^{7}$ Vitamin supplement provides per kilogram diet: vitamin A, 8,000 IU; vitamin E, $20 \mathrm{IU}$; menadione, 3.0 mg; Vitamin. D3, 2,000 IU; riboflavin, 4.0mg; pantothenate, $12 \mathrm{mg}$; nicotinic acid, $50 \mathrm{mg}$; choline $300 \mathrm{mg}$; vitamin B12, $15 \mathrm{mg}$; vitamin B6, $0.12 \mathrm{mg}$; thiamine, $1.5 \mathrm{mg}$; folic acid, $1.00 \mathrm{mg}$; d-biotin, $0.10 \mathrm{mg}$.

${ }^{8}$ Mineral supplement provides per kilogram of diet: trace mineral (as milligrams per kilogram diet) $\mathrm{Mn}, 100 ; \mathrm{Zn}, 70 ; \mathrm{Fe}$ 50; Cu 10; lodine 1; Se, 0.30; antioxidant 50. 
The glutathione peroxidase (GSH) activity was determined in plasma samples using RANDOX kits (Germany) according to the manufacturer's instruction. Plasma lipid peroxidation was determined using the method proposed by Satoh (1978) and Yagi (1984), but with 1,1,3,3-tetraethoxypropane (TMP) as the standard. This method is based on the reaction between malonyldialdehyde (MDA, an aldehyde lipid peroxidation product) and thiobarbituric acid (TBA). The MDA forms a pink-colored complex with TBA. The absorbance of solution containing the complex was measured at $532 \mathrm{~nm}$ using a spectrophotometer (UV1201, Shimadzu, Japan). The plasma lipid peroxidation values were expressed in terms of MDA as $\mathrm{nmol} / \mathrm{mL}$ plasma.

Data were subjected to one-way ANOVA with six treatments and six replicates having eight hens in each replicate. Data obtained were submitted to ANOVA, using the General Linear Model (GLM) procedure of SAS software (SAS 9.3; 2003; SAS Institute Inc., Cary, NC, USA) for Windows. Means were compared by the Duncan's multiple range tests at $5 \%$ probability.

\section{Results}

The effects of experimental diets on productive performance and egg parameters of laying hens are presented in Table 3.

Table 3 Effect of of levels of sunflower meal and a multi-enzyme complex on productive performance and egg parameters of laying hens

\begin{tabular}{|c|c|c|c|c|c|}
\hline Item & $\begin{array}{l}\text { Feed intake } \\
(\mathrm{g} / \mathrm{d} / \mathrm{bird})\end{array}$ & $\begin{array}{c}\text { Egg production } \\
(\%)\end{array}$ & $\begin{array}{l}\text { Egg weight } \\
\text { (g) }\end{array}$ & $\begin{array}{l}\text { Egg mass } \\
\text { (g/d/bird) }\end{array}$ & $\begin{array}{c}\text { Feed efficiency } \\
(\mathrm{g} / \mathrm{g})\end{array}$ \\
\hline \multicolumn{6}{|l|}{$S F M^{1}(\%)$} \\
\hline 0 & 110.10 & 80.01 & 65.18 & 52.15 & 2.11 \\
\hline 10 & 109.82 & 79.12 & 64.54 & 51.06 & 2.15 \\
\hline 20 & 108.71 & 78.27 & 63.29 & 49.54 & 2.19 \\
\hline SEM & 0.70 & 1.45 & 0.71 & 0.85 & 0.04 \\
\hline \multicolumn{6}{|l|}{ Natuzyme (g/ton) } \\
\hline 0 & $110.21^{b}$ & 79.15 & 65.17 & 51.58 & 2.13 \\
\hline 250 & $113.64^{\mathrm{a}}$ & 80.15 & 65.80 & 52.73 & 2.15 \\
\hline SEM & 0.56 & 1.12 & 0.35 & 0.57 & 0.02 \\
\hline \multicolumn{6}{|l|}{ SFM $\times$ Natuzyme } \\
\hline $0 \times 0$ & $110.58^{b}$ & 79.54 & 65.48 & 52.08 & 2.12 \\
\hline $0 \times 250$ & $113.13^{\mathrm{a}}$ & 81.54 & 65.89 & 53.72 & 2.10 \\
\hline $10 \times 0$ & $111.25^{\mathrm{ab}}$ & 78.24 & 64.37 & 50.36 & 2.20 \\
\hline $10 \times 250$ & $112.35^{\mathrm{ab}}$ & 79.15 & 64.88 & 51.35 & 2.18 \\
\hline $20 \times 0$ & $108.45^{\circ}$ & 77.36 & 64.12 & 49.60 & 2.18 \\
\hline $20 \times 250$ & $113.89^{\mathrm{a}}$ & 79.51 & 64.85 & 51.56 & 2.20 \\
\hline SEM & 1.14 & 2.12 & 0.74 & 1.45 & 0.61 \\
\hline \multicolumn{6}{|l|}{$P$-value } \\
\hline SFM & 0.28 & 0.09 & 0.19 & 0.15 & 0.19 \\
\hline Natuzyme & 0.004 & 0.15 & 0.11 & 0.24 & 0.38 \\
\hline SFM × Natuzyme & 0.001 & 0.19 & 0.24 & 0.19 & 0.49 \\
\hline
\end{tabular}

${ }^{1}$ SFM = sunflower meal;

${ }^{\text {a,b }}$ Means within a column with different superscripts differ significantly at $P<0.05$.

No significant differences on egg production, egg weight and mass were observed among dietary treatments. Including 20\% SFM in diet significantly reduced feed intake of hens $(P<0.05)$. Egg specific gravity, shell strength and thickness, Haugh unit and shape index were not affected by dietary treatments (Table 4). 
Table 4 Effect of of levels of sunflower meal and a multi-enzyme complex on egg quality of laying hens

\begin{tabular}{|c|c|c|c|c|c|}
\hline Item & Shell thickness $(\mathrm{mm})$ & $\begin{array}{c}\text { Shell } \\
\text { strength }\left(\mathbf{k g} / \mathrm{cm}^{2}\right)\end{array}$ & $\begin{array}{c}\text { Shape } \\
\text { index (\%) }\end{array}$ & Haugh unit & $\begin{array}{l}\text { Egg specific gravity } \\
\left(\mathrm{g} / \mathrm{cm}^{3}\right)\end{array}$ \\
\hline \multicolumn{6}{|l|}{$S F M^{1}(\%)$} \\
\hline 0 & 0.31 & 3.77 & 74.32 & 81.35 & 1.08 \\
\hline 10 & 0.29 & 3.69 & 74.21 & 81.11 & 1.08 \\
\hline 20 & 0.28 & 3.61 & 74.11 & 80.98 & 1.09 \\
\hline SEM & 0.01 & 0.14 & 1.05 & 1.18 & 0.012 \\
\hline \multicolumn{6}{|l|}{ Natuzyme (g/ton) } \\
\hline 0 & 0.29 & 3.61 & 75.24 & 80.11 & 1.07 \\
\hline 250 & 0.32 & 3.76 & 74.89 & 81.21 & 1.08 \\
\hline SEM & 0.01 & 0.16 & 1.11 & 1.08 & 0.011 \\
\hline \multicolumn{6}{|l|}{$S F M \times$ Natuzyme } \\
\hline $0 \times 0$ & 0.28 & 3.68 & 74.45 & 81.44 & 1.08 \\
\hline $0 \times 250$ & 0.32 & 3.70 & 74.99 & 81.68 & 1.08 \\
\hline $10 \times 0$ & 0.27 & 3.64 & 74.35 & 81.20 & 1.08 \\
\hline $10 \times 250$ & 0.31 & 3.61 & 74.71 & 81.60 & 1.08 \\
\hline $20 \times 0$ & 0.27 & 3.60 & 74.11 & 80.67 & 1.07 \\
\hline $20 \times 250$ & 0.31 & 3.69 & 74.48 & 81.49 & 1.08 \\
\hline SEM & 0.016 & 0.015 & 1.22 & 1.31 & 0.014 \\
\hline \multicolumn{6}{|l|}{$P$ value } \\
\hline SFM & 0.74 & 0.35 & 0.35 & 0.45 & 0.09 \\
\hline Natuzyme & 0.62 & 0.41 & 0.09 & 0.33 & 0.09 \\
\hline SFM ×Natuzyme & 0.39 & 0.66 & 0.12 & 0.52 & 0.71 \\
\hline
\end{tabular}

${ }^{1}$ SFM = sunflower meal;

${ }^{\mathrm{a}, \mathrm{b}}$ Means within a column with different superscripts differ significantly at $P<0.05$.

The effect of dietary treatments on egg weight, yolk weight, and egg yolk cholesterol are reported in Table 5. The egg yolk cholesterol decreased significantly $(P<0.05)$ by supplementation of SFM in the hens' diet. The effect of dietary treatments on changes of plasma HDL- and LDL-cholesterol, atherogenic index and triglycerides are shown in Table 6. In this study, triglycerides level was not affected by diets. However, feeding of SFM increased plasma HDL-cholesterol, but decreased LDL-cholesterol. The atherogenic index was significantly lower $(P<0.05)$ in plasma of group fed diet supplemented with SFM than the other groups. There were no significant effects of dietary treatment on GSH activity and MDA concentration compared to control unsupplemented diet (Table 7). However, the concentration of plasma total cholesterol increased ( $P$ $<0.05$ ) in laying hens fed enzyme at the rate of $250 \mathrm{~g} /$ ton diet.

\section{Discussion}

In the present study, no significant differences on egg production, egg weight and egg mass were observed among dietary treatments. Feeding $20 \%$ of SFM in diet significantly reduced feed intake of hens. Our findings agree those of Rezaei and Hafezian (2007) reporting that the use of high fiber SFM at the level of $15 \%$ in diet reduced feed intake in laying hens. The high fiber content of diet and the reduction of the metabolizable energy resulted responsible of the low feed intake of hens fed SFM when compared to the control diet. Shi et al. (2012) reported that diets supplemented with $8.26,16.52$, and $24.84 \%$ SFM had no significant effect on body weight gain, egg production, egg mass, feed intake or feed conversion in layers. Furthermore, Uwayjan et al. (1983) found that the inclusion of 30\% SFM in diet did not affect feed conversion in hens, but feed consumption was reduced, which might be due to the increase in the energy content of diet. Vieira et al. (1992) observed that SFM in laying hen diet increased feed consumption and influenced negatively feed efficiency. Diets with high fiber contents have lower energetic value, determining a reduction 
of the passage rate through the gastrointestinal tract, and stimulating feed intake to maintain a constant caloric intake.

Table 5 The effects of of levels of sunflower meal and a multi-enzyme complex on egg weight, yolk weight and cholesterol

\begin{tabular}{|c|c|c|c|c|}
\hline Item & Egg weight (g) & Yolk weight (g) & $\begin{array}{c}\text { Total cholesterol } \\
(\mathrm{mg} / \mathrm{yolk})\end{array}$ & $\begin{array}{c}\text { Total cholesterol } \\
(\mathrm{mg} / \mathrm{g} \text { yolk })\end{array}$ \\
\hline \multicolumn{5}{|l|}{$S F M^{1}(\%)$} \\
\hline 0 & 64.10 & 15.42 & $194.9^{\mathrm{a}}$ & $12.64^{\mathrm{a}}$ \\
\hline 10 & 64.02 & 15.35 & $181.2^{\mathrm{ab}}$ & $11.81^{a b}$ \\
\hline 20 & 63.88 & 14.95 & $171.0^{\mathrm{b}}$ & $11.44^{\mathrm{b}}$ \\
\hline SEM & 1.42 & 0.42 & 2.60 & 0.31 \\
\hline \multicolumn{5}{|l|}{ Natuzyme (g/ton) } \\
\hline 0 & 64.02 & 15.35 & 176.6 & 11.51 \\
\hline 250 & 64.13 & 15.42 & 176.7 & 11.46 \\
\hline SEM & 1.137 & 0.40 & 2.62 & 0.4 \\
\hline \multicolumn{5}{|l|}{$S F M \times$ Natuzyme } \\
\hline $0 \times 0$ & 64.01 & 15.45 & $190.8^{a}$ & 12.35 \\
\hline $0 \times 250$ & 64.13 & 15.38 & $187.3^{\mathrm{a}}$ & 12.18 \\
\hline $10 \times 0$ & 64.11 & 15.24 & $180.4^{\mathrm{ab}}$ & 11.84 \\
\hline $10 \times 250$ & 64.15 & 15.35 & $181.3^{\mathrm{ab}}$ & 11.81 \\
\hline $20 \times 0$ & 63.75 & 15.01 & $176.4^{\mathrm{b}}$ & 11.75 \\
\hline $20 \times 250$ & 64.14 & 15.19 & $180.5^{\mathrm{ab}}$ & 11.88 \\
\hline SEM & 1.65 & 0.56 & 2.3 & 0.51 \\
\hline \multicolumn{5}{|l|}{$P$ value } \\
\hline SFM & 0.54 & 0.23 & 0.03 & 0.02 \\
\hline Natuzyme & 0.32 & 0.43 & 0.29 & 0.48 \\
\hline SFM $\times$ Natuzyme & 0.62 & 0.19 & 0.01 & 0.08 \\
\hline
\end{tabular}

${ }^{1} \mathrm{SFM}=$ sunflower meal;

a,b Means within a column with different superscripts differ significantly at $P<0.05$.

The findings obtained in this study were different from those reported by other authors (Rose et al., 1972; Deaton et al., 1979) who observed that SFM in laying hens diet increased feed intake. These differences were probably due to fiber content and digestibility of amino acids of SFM. Supplementing diet with exogenous enzymes induced a significant increase in feed intake. These findings are in line with previous studies reporting that single or multi-enzyme complex lowered positively the anti-nutritional factors effect present in diet, leading to an improvement in growth performance of laying hens (Annison \& Choct, 1991; Cowieson \& Adeola, 2005; Adeola \& Cowieson, 2011; Ravindran, 2013). In a previous study, Kocher et al. (2000) indicated that commercial enzyme products had some effects in diets containing high inclusion levels of SFM. In our trial, egg specific gravity, shell strength and thickness, Haugh unit, and egg shape index were not affected by dietary treatments. Similarly, Rezaei and Hafezian (2007) found no effect of SFM in diet on Haugh unit values. Further, Karunajeewa et al. (1989) observed that hens fed diets containing SFM laid eggs with lower Haugh unit values than those fed SFM with or without supplementation of sunflower oil. In the present study, egg yolk cholesterol was decreased significantly $(P<0.05)$ by supplementation of SFM in diet. This result is in agreement with the findings of Shi et al. (2012) and Laudadio et al. (2014a) who reported a significant decrease in egg yolk cholesterol when soybean meal was replaced with SFM. This appears to be appealing for consumers because of higher circulating cholesterol level as one of the major health risk factors related to cardiac problems (Laudadio et al., 2015). Thus, including SFM in poultry diet can be beneficial due to the effect of fiber in reducing cholesterol. One mechanism through SFM may exert its hypocholesterolemic action is via bile acids. The cholic and 
deoxycholic bile acids are produced from cholesterol by hepatocytes and are conjugated with glycine and taurine, respectively.

Table 6 Effect of levels of sunflower meal and a multi-enzyme complex on plasma biochemical parameters of laying hens

\begin{tabular}{lcccc}
\hline Item & $\begin{array}{c}\text { LDL-cholesterol } \\
(\mathbf{m g} / \mathbf{d L})\end{array}$ & $\begin{array}{c}\text { HDL-cholesterol } \\
(\mathbf{m g} / \mathbf{d L})\end{array}$ & $\begin{array}{c}\text { Atherogenic } \\
\text { index }\end{array}$ & $\begin{array}{c}\text { Triglycerides } \\
(\mathbf{m g} / \mathbf{d L})\end{array}$ \\
\hline$S F M^{1}(\%)$ & & & & \\
0 & $105.6^{\mathrm{a}}$ & $40.7^{\mathrm{b}}$ & $2.63^{\mathrm{a}}$ & 1414.2 \\
10 & $103.2^{\mathrm{ab}}$ & $42.6^{\mathrm{ab}}$ & $2.43^{\mathrm{ab}}$ & 1387.4 \\
20 & $98.6^{\mathrm{b}}$ & $48.1^{\mathrm{a}}$ & $1.98^{\mathrm{b}}$ & 1382.2 \\
SEM & 2.01 & 1.98 & 0.15 & 105.35 \\
Natuzyme (g/ton) & & & & \\
0 & 104.20 & 41.25 & 2.52 & 1392.3 \\
250 & 104.01 & 41.19 & 2.52 & 1400.0 \\
SEM & 2.62 & 3.36 & 0.29 & 110.35 \\
SFM $\times$ Natuzyme & & & & \\
$0 \times 0$ & 103.26 & $41.21^{\mathrm{b}}$ & $2.50^{\mathrm{a}}$ & 1405.8 \\
$0 \times 250$ & 102.41 & $44.31^{\mathrm{ab}}$ & $2.31^{\mathrm{ab}}$ & 1412.2 \\
$10 \times 0$ & 100.20 & $48.24^{\mathrm{ab}}$ & $2.07^{\mathrm{ab}}$ & 1387.2 \\
$10 \times 250$ & 101.35 & $46.37^{\mathrm{ab}}$ & $2.18^{\mathrm{ab}}$ & 1381.7 \\
$20 \times 0$ & 100.10 & $49.67^{\mathrm{ab}}$ & $2.01^{\mathrm{ab}}$ & 1369.4 \\
$20 \times 250$ & 100.00 & $51.23^{\mathrm{ab}}$ & $1.95^{\mathrm{b}}$ & 1376.4 \\
SEM & 2.29 & 0.13 & 122.38 \\
$P$ value & 2.89 & & & \\
SFM & & 2.29 & 0.03 & 0.45 \\
Natuzyme & 0.02 & 0.02 & 0.45 & 0.58 \\
SFM $\times$ Natuzyme & 0.32 & 0.38 & 0.01 & 0.33 \\
& 0.18 & 0.00 & &
\end{tabular}

${ }^{1} \mathrm{SFM}=$ sunflower meal; $\mathrm{LDL}=$ low-density lipoprotein; $\mathrm{HDL}=$ high-density lipoprotein

a,b Means within a column with different superscripts differ significantly at $P<0.05$.

These acids enter the small intestine, where they are absorbed and directed to liver, and a decrease in bile acid recycling would ultimately result in a lowering of serum cholesterol because of cholesterol is involved in bile acid synthesis (St-Onge et al., 2000). However, we did not measure the amount of bile acid synthesis to support this statement. Fiber content of SFM may stimulate binding of cholesterol with bile acids, and inhibition of micelle formation combined with the effect of fermentation on short chain fatty acids production are mechanisms that have been proposed to explain the potential cholesterol lowering effects (StOnge et al., 2000). The B-group vitamins' content of SFM is remarkably higher than that of SBM (Lebiedzinska \& Szefer, 2006). These vitamins in SFM, especially niacin, play an important role in increasing HDL- and decreasing LDL-cholesterol. The SFM is also high in niacin, riboflavin, choline, biotin, pantothenic acid and pyridoxine (Grau \& Almquist, 1945). Niacin intensified fatty acid oxidation would determine accumulation of acetyl-CoA which in turn inhibits cholesterol synthesis. On the other hands, nicotinamide adenine dinucleotide $\left(\mathrm{NAD}^{+}\right)$or acetyl-CoA would also activate $7 \alpha$-hydroxylase, which allows biliary acid formation from cholesterol and would amplify its catabolism and excretion. In the current trial, dietary supplementation of SFM increased HDL-cholesterol, but decreased LDL-cholesterol in plasma; moreover, the atherogenic index was significantly lower in hens fed diet supplemented with SFM than in control diet.

The fiber content of SFM produces short-chain fatty acids (SCFA), when fermented by intestinal microorganisms, containing acetate, propionate and butyrate. Wolever et al. (1991) found that acetate increases total cholesterol and decreases unsaturated fatty acids, and that propionate increases blood glucose, lowering the hypercholesterolemic response caused by acetate (a precursor of cholesterol). This 
effect was observed when the same authors showed that propionate inhibits acetate incorporation into plasma triacylglycerol and tends to inhibit ${ }^{13} \mathrm{C}$ incorporation from labeled acetate into plasma cholesterol (Wolever et al., 1995). For gut bacterial fermentation to play the role in the hypolipidemic effect of a specific food/feed, enough propionate must be produced to offset the effects of acetate generation as a precursor for lipid synthesis (Jenkins et al., 1991). An increase in bacterial count or a change in the composition of the bacterial population in the large intestine would result in increased fermentation and SCFA production. Depending on the proportion of each fatty acid produced, plasma cholesterol concentrations may thus be altered through this mechanism.

Table 7 Effect of of levels of sunflower meal and a multi-enzyme complex on plasma glutathione peroxidase (GSH) activity, malondialdehyde (MDA), and cholesterol of laying hens

\begin{tabular}{lccc}
\hline Item & GSH (U/ml) & MDA (nmol/ml) & $\begin{array}{c}\text { Total Cholesterol } \\
(\mathbf{m g} / \mathbf{d L})\end{array}$ \\
\hline SFM ${ }^{1}(\%)$ & & & \\
0 & 850.4 & 4.45 & 96.4 \\
10 & 839.2 & 4.38 & 89.5 \\
20 & 845.4 & 4.40 & 88.3 \\
SEM & 41.23 & 0.30 & 6.39 \\
Natuzyme (g/ton) & & & \\
0 & 835.3 & 4.68 & $95.4^{\mathrm{b}}$ \\
250 & 830.1 & 4.52 & $115.4^{\mathrm{a}}$ \\
SEM & 38.23 & 0.29 & 4.39 \\
SFM $\times$ Natuzyme & & & \\
$0 \times 0$ & 829.4 & 4.78 & 95.4 \\
$0 \times 250$ & 826.5 & 4.71 & 97.3 \\
$10 \times 0$ & 821.2 & 4.69 & 87.4 \\
$10 \times 250$ & 831.3 & 4.74 & 91.9 \\
$20 \times 0$ & 831.1 & 4.62 & 88.2 \\
$20 \times 250$ & 816.3 & 4.68 & 92.2 \\
SEM & 44.5 & 0.31 & 7.88 \\
$P$ value & & & \\
SFM & & 0.29 & 0.19 \\
Natuzyme & 0.45 & 0.47 & 0.04 \\
SFM $\times$ Natuzyme & 0.52 & 0.36 & 0.15 \\
& 0.69 & &
\end{tabular}

${ }^{1} \mathrm{SFM}=$ sunflower meal;

${ }^{a, b}$ Means within a column with different superscripts differ significantly at $\mathrm{P}<0.05$.

In our study no significant differences were seen among dietary treatments on plasma GSH activity and MDA concentration compared to unsupplemented diet. However, the concentration of plasma cholesterol was increased in hens fed enzyme-supplemented diet $(250 \mathrm{~g} / \mathrm{ton})$. These results were similar to those reported by Salem et al. (2008) who indicated that, enzyme inclusion (at $0.5 \mathrm{~g} / \mathrm{kg}$ ) to layers diet significantly increased plasma cholesterol by $14.7 \%$ compared to control group. In agreement with the present trial, Khan et al. (2011) reported that supplementation of enzyme $(2.0 \mathrm{~g} / \mathrm{kg})$ and probiotic $(0.5 \mathrm{~g} / \mathrm{kg})$ in hens' diet significantly increased plasma cholesterol level. Such increase in plasma cholesterol concentrations may be due to an increase in fiber degradability or digestibility.

\section{Conclusion}

The dietary supplementation with SFM and a multi-enzyme complex in laying hens diet did not appear to cause any adverse effect on egg production and quality as well on the antioxidant status of laying hens. 
Moreover, the supplementing diet with SFM may lead to the development of low-cholesterol table eggs as demanded by health-conscious consumers.

\section{Acknowledgments}

The authors would like to thank the manager of Urmia Youvalar Layer Farm, Mr. Jamshid Azimi for financial support of this study.

\section{Authors' Contributions}

All the authors equally contributed and commented on early and final version of manuscript.

\section{Conflict of Interest Declaration}

The authors have no conflict of interest to declare.

\section{References}

Adeola, O. \& Cowieson, A.J., 2011. Board-invited review: Opportunities and challenges in using exogenous enzymes to improve nonruminant animal production. J. Anim. Sci. 89, 3189-3218.

Alagawany, M., Faraj, M.R., Abd El-Hack, M.E. \& Dhama, K. 2015. The practical application of sunflower meal in poultry nutrition. Adv. Anim. Vet. Sci. 3, 634-648.

Annison, G. \& Choct, M., 1991. Anti-nutritive activities of cereal non-starch polysaccharides in broiler diets and strategies minimizing their effects. World Poult. Sci. J. 47, 232-242.

Association of Official Analytical Chemists (AOAC)., 2000. Official Methods of Analysis. Arlington, VA, USA.

Casartelli, E.M., Filardi, R.S., Junqueira, O.M., Laurentiz, A.C., Assuena, V. \& Duarte, K.F., 2006. Sunflower meal in commercial layer diets formulated on total and digestible amino acids basis. Braz. J. Poult. Sci. 8,167-171.

Cowieson, A.J. \& Adeola, O., 2005. Carbohydrase, protease, and phytase have an additive beneficial effect in nutritionally marginal diets for broiler chicks. Poult. Sci. 841, 860-1867.

de Morais Oliveira, V.R., de Arruda, A.M.V., Silva, L.N.S., de Souza, J.B.F., de Queiroz, J.P.A.F., da Silva Melo, A., \& Holanda, J.S., 2016. Sunflower meal as a nutritional and economically viable substitute for soybean meal in diets for free-range laying hens. Anim. Feed Sci. Technol. 220, 103-108.

Deaton, J.W., McNaughton, J.L. \& Burdick, D., 1979. High-fiber sunflower meal as a replacement for soybean meal in layer diets. Brit. Poult. Sci. 20,159-162.

Elkin, R.G. \& Rogler J.C., 1990. Reduction of the cholesterol content of eggs by the oral administration of lovastatin to laying hens. J. Agr. Food Chem. 38, 1635-1641.

Grau, C.R. \& Almquist, H.J., 1945. The value of sunflower seed protein. Proc. Soc. Exp. Biol. Med. 60, 373-374.

Jenkins, D.J.A., Wolever, T.M.S. \& Jenkins, A., 1991. Specific types of colonic fermentation may raise low-density lipoprotein-cholesterol concentrations. Am. J. Clin. Nutr. 54, 141-147.

Karunajeewa, H., Than, S.H. \& Abu-Serewa, S., 1989. Sunflower seed meal, sunflower oil and full-fat sunflower seeds, hulls and kernels for laying hens. Anim. Feed Sci. Technol. 26, 45-54.

Khan, S.H., Atif, M., Mukhtar, N., Rehman A. \& Fareed, G., 2011. Effects of supplementation of multi-enzyme and multispecies probiotic on production performance, egg quality, cholesterol level and immune system in laying hens. $J$. Appl. Anim. Res. 39, 386-398.

Khan, S.H., Sardar, R. \& Siddique B., 2006. Influence of enzymes on performance of broilers fed sunflower-corn based diets. Pak. Vet. J. 26, 109-114.

Kocher, A., Chret, M., Porter, M.D. \& Broz J., 2000. The effects of enzyme addition to broiler diets containing high concentrations of canola or sunflower meal. Poult. Sci. 79, 1767-1774.

Laudadio, V., Bastoni, E., Introna, M. \& Tufarelli, V. 2013. Production of low-fiber sunflower (Helianthus annuus L.) meal by micronization and air classification processes. CyTA J. Food. 11, 398-403.

Laudadio, V., Ceci, E., Lastella, N.M.B. \& Tufarelli, V., 2014a. Effect of feeding low-fiber fraction of air-classified sunflower (Helianthus annus L.) meal on laying hen productive performance and egg yolk cholesterol. Poult. Sci. 93, 2864-2869.

Laudadio, V., Ceci, E., Nahashon, S.N., Introna, M., Lastella, N.M.B. \& Tufarelli, V., 2014c. Influence of substituting dietary soybean for air-classified sunflower (Helianthus annuus L.) meal on egg production and steroid hormones in early-phase laying hens. Reprod. Dom. Anim. 49, 158-163.

Laudadio, V., Introna, M., Lastella, N.M.B. \& Tufarelli, V., 2014b. Feeding of low-fibre sunflower (Helianthus annus L.) meal as substitute of soybean meal in turkey rations: Effects on growth performance and meat quality. J. Poult. Sci. 51, 185-190.

Laudadio, V., Ceci, E., Lastella, N.M.B., \& Tufarelli, V., 2015. Dietary high-polyphenols extra-virgin olive oil is effective in reducing cholesterol content in eggs. Lipids Health Dis.14, 5.

Lebiedzinska, A., \& Szefer, P., 2006. Vitamin B in grain and cereal-grain food, soy products and seeds. Food Chem. 95, $116-122$.

Lee, K.W., Choi, Y.I., Moon, E.J., Oh, S.T. \& Lee, H.H., 2014. Evaluation of dietary multiple enzyme preparation (Natuzyme) in laying hens. Asian-Australas. J. Anim. Sci. 27, 1749-1754.

National Research Council (NRC)., 1994. Nutrient Requirements of Poultry, 9th edition, National Academy Press. Washington, D.C.

Pesti, G.M., \& Miller, B.R., 1992. Animal Feed Formulation: Economic and Computer Applications. Nostrand Reinhold (Van), New York, NY. 
Ravindran, V., 2013. Feed enzymes: The science, practice, and metabolic realities. J. Appl. Poult. Res. 22, 628-636.

Rezaei, M. \& Hafezian, H., 2007. Use of different levels of high fiber sunflower meal in commercial Leghorn type layer diets. Int. J. Poult. Sci. 6, 431-433.

Rose, R.J., Coit, R.N. \& Sell, J.L., 1972. Sunflower seed meal as a replacement for soybean meal protein in laying hen rations. Poult. Sci. 51, 960-967.

Salem, A.A., El-Anwer, E.M.M., Abo-Eita, E.M.M. \& Namra, M.M.M., 2008. Productive and physiological performance of golden montazah male chickens as affected by feed restriction and avizyme supplementation. Egypt Poult. Sci. 28, 1137-1164.

SAS Institute, 2003. SAS/STAT User's Guide. Release 9.3 Ed. SAS Institute Inc., Cary, NC.

Sateri, S., Seidavi, A., Bouyeh, M., Neumann, P., Kutzler, M., Laudadio, V., F. Loperfido \& Tufarelli, V., 2017. Effect of olive meal and supplemental enzymes on performance traits, blood biochemistry, humoral immunity response and caecal microbiota of broilers. S. Afr. J. Anim. Sci. 47, 804-812.

Satoh, K., 1978. Serum lipid peroxide in cerebrovascular disorder determined by a new colorimetric method. Clin. Chim. Acta 90, 37-43.

Senkoylu, N. \& Dale, N., 1999. Sunflower meal in poultry diets: a review. World Poult. Sci. J. 55, 153-174.

Shi, S.R., Lu, J., Tong, H.B., Zou, J.M. \& Wang, K.H., 2012. Effects of graded replacement of soybean meal by sunflower seed meal in laying hen diets on hen performance, egg quality, egg fatty acid composition, and cholesterol content. J. Appl. Poult. Res. 21, 367-374.

St-Onge, M.P., Farnworth E.R. \& Jones, P.J.H., 2000. Consumption of fermented and nonfermented dairy roducts: effects on cholesterol concentrations and metabolism. Am. J. Clin. Nutr. 71, 674-681.

Tsuzuki, E.T., de Garcia, E.R.M., Murakami, A.E., Sakamoto, M.I. \& Galli J.R., 2003. Utilization of sunflower seed in laying hen rations. Braz. J. Poult. Sci. 5, 179-182.

Tufarelli, V., Dario, M., \& Laudadio, V., 2007. Effect of xylanase supplementation and particle-size on performance of guinea fowl broilers fed wheat-based diets. Int. J. Poult. Sci. 4, 302-307.

Ulbricht, T.L.V., \& Southgate, D.A.T., 1991. Coronary heart disease: seven dietary factors. Lancet 338, 982-992.

Uwayjan, M.G., Azar, E.J. \& Daghir, N.J., 1983. Sunflower seed in laying hen rations. Poult. Sci. 62, 1247-1253.

Vieira, S.L., Penz, A.M., Leboute, E.M. \& Corteline, J., 1992. A nutritional evaluation of a high fibre sunflower meal. J. Appl. Poult. Res. 1, 382-388.

Wolever, T.M.S., Spadafora, P.J. \& Eshuis, H., 1991. Interaction between colonic acetate and propionate in humans. Am. J. Clin. Nutr. 53, 681-687.

Wolever, T.M.S., Spadafora, P.J., Cunnane, S.C. \& Pencharz, P.B., 1995. Propionate inhibits incorporation of colonic [1, 2-13C] acetate into plasma lipids in humans. Am. J. Clin. Nutr. 61, 1241-1247.

Yagi, K., 1984. Assay for blood plasma or serum. Method Enzymol. 105, 328-331. 